\title{
Prevalence of Keratoconus among Young Arab Students in Israel
}

\author{
${ }^{1}$ Einat Shneor, ${ }^{2}$ Michel Millodot, ${ }^{3}$ Ariela Gordon-Shaag, ${ }^{4}$ Maron Essa, ${ }^{5}$ Miriam Anton \\ ${ }^{6}$ Ramez Barbara, ${ }^{7}$ Adel Barbara
}

\begin{abstract}
Purpose: To determine the prevalence of keratoconus $(\mathrm{KC})$ in an Arab population in Israel.
\end{abstract}

Materials and methods: Videokeratography was performed on volunteer students from the Academic Arab College of Education, in Haifa, Israel. All participants filled out a self-administered questionnaire to evaluate possible risk factors for KC. Univariate and multivariate analysis were performed.

Results: Data of 314 participants were analyzed and a prevalence of $(\mathrm{N}=10), 3.18 \%(95 \% \mathrm{Cl}, 1.2$ to $5.1 \%)$ was found. The only significant factor (both in univariate and multivariate analysis) that was associated with $\mathrm{KC}$ was parental consanguinity (OR 5.10, $p=0.02$ ). Druzes and Bedouins had a higher prevalence than Muslims and Christians. However, the differences were not significant possibly due to the small size of the sample.

Conclusion: The result of this study was similar to other studies conducted in the Middle East, which indicate a higher prevalence of $\mathrm{KC}$ than in western countries. It is also recommended that people who have consanguinity in their family should be topographically tested to detect the early stages of KC.

Keywords: Keratoconus, Consanguinity, Videokeratography.

How to cite this article: Shneor E, Millodot M, Gordon-Shaag A, Essa M, Anton M, Barbara R, Barbara A. Prevalence of Keratoconus among Young Arab Students in Israel. Int J Kerat Ect Cor Dis 2014;3(1):9-14.

Source of support: Nil

Conflict of interest: None declared

\section{INTRODUCTION}

Keratoconus $(\mathrm{KC})$ is a corneal disorder of uncertain etiology in which the central portion of the cornea becomes thinner

\footnotetext{
${ }^{1,3}$ Senior Lecturer, ${ }^{2}$ Professor, ${ }^{4,5}$ Optometrist ${ }^{6,7}$ Private Practice

${ }^{1,3-5}$ Department of Optometry and Vision Science, Hadassah Academic College, Jerusalem, Israel

${ }^{2}$ Department of Optometry, School of Optometry, The Hong Kong Polytechnic University, Hong Kong

${ }^{6,7}$ The Center for the Treatment of Keratoconus, Haifa, Israel

Corresponding Author: Einat Shneor, Senior Lecturer Department of Optometry and Vision Science, Haniviim St. 37 Pob 114, Jerusalem-91010, Israel, Phone: 972-26291959, Fax: 972-26250619, e-mail: eshneor@hotmail.com
}

and bulges forward in a cone-shaped fashion resulting in myopia, irregular astigmatism and eventually visual impairment. ${ }^{1-3}$ The disease has its usual onset at puberty and in many cases progresses until the third and fourth decade of life when it usually arrests..$^{3-5,6}$

In the last few years, there have been several reports of prevalence rates of $\mathrm{KC}$, which have revealed large differences based on geographical locations and ethnic groups. Generally, countries with sunny and warm climates, such as India, ${ }^{7}$ Israel, ${ }^{8}$ Lebanon,,${ }^{9}$ Iran, ${ }^{10,11}$ Saudi Arabia ${ }^{12}$ and Australia ${ }^{13}$ have been found to have higher prevalence than cooler countries such as the USA, Europe and Russia. ${ }^{14-20}$ This large discrepancy could be accounted for by the different amount of sun exposure prevailing in these countries, since, ultraviolet light as a source of oxidative stress could play a role in the etiology of the disease. ${ }^{21}$ However, to the best of our knowledge there has not been a study relating an association between $\mathrm{KC}$ and sun exposure.

Another consideration could be the ethnic differences of the populations in these countries. Indeed in two surveys done in the UK, Asians (Bangladeshis, Indians and Pakistanis) were found to have a KC prevalence 4.4 and 7.5 times greater than white Caucasians. ${ }^{18,19}$ Likewise, Japanese have been reported to have a prevalence of $\mathrm{KC}$ less than one-third that of white Caucasians. ${ }^{22}$ Prevalence was $2.5 \%$ in a Persian ethnic group and $7.5 \%$ among non-Persians (Arabs, Kurds, Turks) in Iran. ${ }^{10}$ and in a comparison of the three major ethnic groups of Singapore (Chinese, Malays and Indians), Indians had significantly steeper corneas than the other groups. ${ }^{23}$ Endogamy and/or consanguinity would appear to play a major role in these communities, as was shown in a recent study. ${ }^{24}$ However, ethnic differences do not appear to prevail universally since similar KC prevalence was observed in India ${ }^{7}$ and China. ${ }^{25}$ In a study of prevalence conducted in Israel ${ }^{8}$ there was a small but not statistically significant difference between Israeli, Arabs and Jews. This lack of significance could have been due to the large difference in sample size, being $n=200$ for Arabs and $\mathrm{n}=766$ for Jews. Thus, it was felt that a larger sample size of Arabs was warranted and this study aims to evaluate the true KC prevalence of an Arab population in Israel as well as to ascertain some of the risk factors of the disease. 


\section{MATERIALS AND METHODS}

The student population of the Academic Arab College of Education was chosen for this survey. The college is located in Haifa, Israel and has a student body of approximately 2,500, exclusively from Arabic-speaking ethnicities.

All students received an e-mail inviting them to participate in this non-invasive screening test for $\mathrm{KC}$ with a short explanation of the signs and symptoms of the disease and that in the early stages there may be no visual symptoms. The e-mail stressed that it is important for all students to be tested.

Students who participated in the screening study were asked to complete an anonymous self-administered questionnaire, based on one used previously. ${ }^{8,24,26-28}$ The questionnaire included questions relating to age, sex, domicile, family history of $\mathrm{KC}$, contact lens wear, sun-glasses, relation between the parents and relation of the father's parents, allergies and eye rubbing. Ethnicity was determined by questions on religion (Christian, Muslim, Druze, else) and whether or not they define themselves as Bedouin. Muslim Arabs were classified as a different enthnicity than Muslim Bedouins. ${ }^{29}$

Exclusion criteria were subjects with contact lens warpage, who had undergone refractive or corneal surgery (except for $\mathrm{KC}$ management), who had been diagnosed with an ocular disease other than $\mathrm{KC}$ and who worm hard contact lenses. Students with Arab parent were included in the study. The nature of the study was explained to the students before signing an informed consent form. The study followed the tenets of the Declaration of Helsinki and was approved by Hadassah College ethics committee. The survey was carried out between December 2012 and April 2013 and both males and females, between the ages of 18 and 60, were surveyed.

\section{Data Collection}

Videokeratography was performed on both the eyes of each subject using a TMS-4 corneal topographer (Tomey Corp. Nagoya, Japan). The test was performed by an optometry student trained in the correct use of the instrument with the supervision of a registered optometrist. Contact lens wearers were asked to remove them immediately prior to the examination. Proper fixation and alignment were ascertained when the cross-hair was in the center of the pupil. Two images of each eye were taken and the best topographic image that displayed the largest area of cornea and had the least distortions was selected.

The Tomey TMS-4 Topographic Modeling System includes KC screening software which provides KCI and KPI indices. These indices have been shown to have high sensitivity and specificity. ${ }^{30}$ The color-coded corneal map of each participant was examined by three investigators who were blind to the results of the questionnaire. The dioptric power of the corneal apex and the maximum dioptric difference between the corneal apex and a spot in the middle of the superior half of the cornea (IS) was calculated as well.

On the basis of the videokeratographic indices and the clinical assessments an eye was defined as manifest $\mathrm{KC}$ if it fulfilled the following: KSI $>0 \%$; KPI $>0 \%$; clear topographic pattern; corneal apex $>50 \mathrm{D}$ and/or IS $>3.5 \mathrm{D} .^{8}$

\section{STATISTICAL ANALYSIS}

Prevalence and $95 \%$ confidence intervals (CI) of all subjects, males and females were calculated. If a person had $\mathrm{KC}$ in one eye only or both eyes, that person was defined as having the disease. Univariate analyses were performed using standard non-parametric and parametric tests (Fisher's exact test if any of the expected frequencies was less than 5 , and the t-test) to determine whether sex, ethnicity, family history of $\mathrm{KC}$, sunglasses, education, parent's relatives, atopy or eye rubbing were significantly associated with KC. Multivariate logistic regression analysis was performed to explore the association between $\mathrm{KC}$ (the outcome variable) and the independent predictors, which had been found significant in the univariate analysis using a statistical software package. The predictor variables were binary and coded as ' 1 ' (KC present) and ' 0 ' (KC absent), ' 1 ' for male and ' 0 ' for female. Adjusted odds ratios (OR) as a measure of association while controlling for the effects of the other predictors, and 95\% confidence intervals (CI) were calculated. All tests were two-tailed and $\mathrm{p}$ values lower than 0.05 were considered statistically significant.

\section{RESULTS}

A total of 450 students (18\% of the total number of students in the college) volunteered to participate in the study. Despite the fact that the examiners encouraged the subjects to participate in all aspects of the study, there was not $100 \%$ compliance and 136 subjects were excluded, because, they did not fill out the questionnaire and/or had very poor photographic images and/or did not undergo imaging. As a result, a total of 314 met the eligibility criteria, were examined and completed the questionnaire. The mean (SD) age of the participants was $25.05 \pm 8.83$ (range 18-60) with 38 (12.1\%) males and 276 $(87.9 \%)$ females and the former were significantly older than the latter $(31.19 \pm 13.41$ for males vs $24.23 \pm 7.68$ for females; $p<0.001)$.

Out of the participants, 35 (11.15\%) were Christian, 179 (57.01\%) were Muslim, 65 (20.70\%) were Druze and 33 (10.51\%) were of Bedouin origin (Table 1$)$.

Table 2 gives the characteristics of the $\mathrm{KC}$ and control groups. $\mathrm{KC}$ was found in 10 subjects ( 16 eyes, 9 right eyes, 7 left eyes) individuals representing a prevalence of $3.18 \%$ (95\% CI, 1.2-5.1\%). Six subjects had KC in both eyes. KC 
Prevalence of Keratoconus among Young Arab Students in Israel

Table 1: Ethnic groups, gender and age of sample population

\begin{tabular}{lllllll}
\hline & Muslim & Druze & Christian & Bedouin & Other & Total \\
\hline All (\%) & $179(57)$ & $65(20.7)$ & $35(11.2)$ & $33(10.5)$ & $2(0.6)$ & 314 \\
Mean age (SD) & $23.8(7.3)$ & $24.5(7.4)$ & $33.8(13.9)$ & $21.6(2.1)$ & $24(0)$ & $25.05(8.83)$ \\
Female & 163 & 55 & 30 & 26 & 2 & 276 \\
Male & 17 & 10 & 5 & 6 & 0 & 38 \\
\hline
\end{tabular}

Table 2: Prevalence of $K C$ in the different groups

\begin{tabular}{|c|c|c|c|c|c|c|c|c|}
\hline & $K C$ & Normal & All & $\begin{array}{l}\text { Prevalence } \\
\text { KC (\%) }\end{array}$ & $95 \% \mathrm{Cl}$ & $95 \% \mathrm{Cl}$ & OR & $p$-value \\
\hline Subjects & 10 & 304 & 314 & 3.18 & & & & \\
\hline Range_-Age (years) & $19-28$ & $18-60$ & $18-60$ & & & & & \\
\hline Average age (SD) & $25.1(8.8)$ & $25.2(8.9)$ & $25.1(8.8)$ & & & & & \\
\hline Male-N (\%) & $2(20)$ & $36(11.8)$ & $38(12.2)$ & 5.26 & 0.38 & 9.11 & 1.86 & $\begin{array}{l}0.346 \text { * } \\
\text { (Male vs Female) }\end{array}$ \\
\hline $\begin{array}{l}\text { Male_Average age } \\
\text { (SD) }\end{array}$ & $23.50(15.9)$ & $31.63(13.4)$ & $31.19(13.4)$ & & & & & $\begin{array}{l}0.88^{* *} \\
\text { (KC vs Control) }\end{array}$ \\
\hline Female-N (\%) & $8(80)$ & $268(88.2)$ & 276 (87.9) & 2.90 & & & & \\
\hline $\begin{array}{l}\text { Female_Average } \\
\text { age (SD) }\end{array}$ & $21.57(10)$ & $24.30(7.6)$ & $24.24(7.7)$ & & & & & $\begin{array}{l}0.49 * * \\
\text { (KC vs Control) }\end{array}$ \\
\hline Muslim ${ }^{\dagger}(\%)$ & $4(40)$ & $175(57.6)$ & $179(57)$ & 2.2 & 0.14 & 1.78 & 0.49 & $0.337^{*}$ \\
\hline Druze (\%) & $3(30)$ & $62(20.4)$ & $65(20.7)$ & 4.6 & 0.42 & 6.66 & 1.67 & $0.437^{*}$ \\
\hline Christian (\%) & $1(10)$ & $34(11.2)$ & $35(11.1)$ & 2.9 & & & & $1.0^{*}$ \\
\hline Bedouin (\%) & $2(20)$ & $31(10.2)$ & $33(10.5)$ & 6.1 & 0.45 & 10.83 & 2.2 & 0.283 * \\
\hline Other (\%) & $0(0)$ & $2(0.7)$ & $2(0.6)$ & & & & & $1.0^{*}$ \\
\hline
\end{tabular}

* Fisher's test; ${ }^{* *}$ t-test; ${ }^{\dagger}$ excluding Bedouin

prevalence was found to be $2.90 \%(95 \% \mathrm{CI}, 0.9-4.9 \%)$ in women and $5.26 \%(1.8-12.3 \%)$ in men, but this was not statistically significant $(p=0.35$, Fisher's test). Six $(60 \%)$ subjects out of the 10 subjects diagnosed with $\mathrm{KC}$ did not know about their condition.

The steepening was located inferiorly in all eyes. All keratoconic eyes had irregular astigmatism. In all 10 cases the $\mathrm{KCI}$ and $\mathrm{KSI}$ indices were indicative of $\mathrm{KC}$. The mean (SD) corneal power of the apex of the cone of the most severely affected eye of each subject was $50.02 \pm 4.10 \mathrm{D}$ and the I-S was $8.64 \pm 3.52 \mathrm{D}$.

The prevalence of KC in Muslims (excluding Bedouins) was $2.2 \%$ (CI $0.05-4.3 \%$ ), in Druzes $4.6 \%$ (CI $0.5-9.7 \%$ ), in Christians 2.9\% (CI 0.1\%-5.7\%) and in Bedouins 6.1\% (CI 2.04-14.2\%). The results are summarized in Table 2.

Table 3 presents the univariate results of the various independent factors evaluated in $\mathrm{KC}$ and controls. Neither eye rubbing, allergy, sex, religion, family history of $\mathrm{KC}$ and habitual wear of sunglasses were found not to be significant. A significant association was only found between $\mathrm{KC}$ and parental first-cousin consanguinity (Fisher's test, $\mathrm{p}=0.017$, OR 5.08, CI 1.42-18.20), between KC and father's parental first-relation consanguinity (Fisher's test, $\mathrm{p}=0.006$, OR 4.00, CI 1.94-25.31,) and for more than 16 years of education (Fisher's test, $\mathrm{p}=0.011$, OR 9.59, CI 2.22-41.40). The multivariate logistic regression was performed with only 2 variables: parental first-cousin consanguinity and edu- cation for more than 16 years of education, because of the intra-dependence between parents and first-relation consanguinity. We found only parental first-cousin consanguinity to be significant (OR 5.10, 95\% CI 1.41-18.33, $\mathrm{p}=0.02$ ).

\section{DISCUSSION}

This study assessed the prevalence of $\mathrm{KC}$ in a population of Arab students in Haifa, Israel. A prevalence of $3.18 \%(95 \% \mathrm{CI})$ was found, with a higher, but not statistically significant prevalence for men. These results are consistent to the results of other recent population studies in Israel, ${ }^{8}$ Iran, ${ }^{10,11}$ and Lebanon ${ }^{9}$ (Table 4). This is in contrast to studies from Western countries that demonstrate a lower prevalence. ${ }^{2}$

The current study identified consanguinity as a significant risk factor for KC in Israeli Arabs. Gordon-Shaag et al found similar results for Palestinian Arabs. ${ }^{24,31}$ While the studies in Iran, ${ }^{10,11,32}$ Lebanon $^{9}$ and Saudi Arabia ${ }^{12}$ did not address this issue, these countries are known for a high degree of consanguinity. ${ }^{24,33-40}$ Taken together, this indicates a genetic autosomal recessive pathogenesis for the disease, at least in this region. The genetic etiology is supported by three additional lines of evidence. First, KC patients report a positive family history of the disease ${ }^{16,24,28,41-46}$ although it was not evident in our study possibly because of the small sample. Second, is the report of $\mathrm{KC}$ concordance between monozygotic twins. ${ }^{47-49}$ Third, is genetic linkage analysis and association studies. ${ }^{20,41,50-65}$ 
Table 3: Results of the univariate analysis

\begin{tabular}{|c|c|c|c|c|c|c|c|}
\hline & $K C$ & Normal & $\begin{array}{l}\text { Prevalence } \\
\text { KC (\%) }\end{array}$ & $95 \% \mathrm{Cl}$ & $95 \% \mathrm{Cl}$ & OR & $P$-value* \\
\hline Gender (men) & 2 & 36 & 0.64 & 0.38 & 9.11 & 1.86 & 0.35 \\
\hline Family history of $\mathrm{KC}$ & 0 & 13 & 0 & & & & 1 \\
\hline Eye rubbing & 4 & 72 & 1.27 & 0.59 & 7.82 & 2.15 & 0.26 \\
\hline Allergy ${ }^{\dagger}$ & 1 & 41 & 0.32 & & & & 1 \\
\hline Sunglasses & 5 & 159 & 1.59 & & & & 1 \\
\hline Parental first-cousin consanguinity & 5 & 50 & 1.59 & 1.42 & 18.20 & 5.08 & 0.02 \\
\hline $\begin{array}{l}\text { Father's parent first-relation } \\
\text { consanguinity }\end{array}$ & 5 & 38 & 1.59 & 1.94 & 25.31 & 4.00 & 0.01 \\
\hline \multicolumn{8}{|l|}{ Years of education } \\
\hline 12 years & 1 & 16 & 0.32 & 0.24 & 16.77 & 2.00 & 0.43 \\
\hline $12-16$ years & 6 & 206 & 1.91 & 0.20 & 2.59 & 0.71 & 0.733 \\
\hline More than 16 years & 3 & 13 & 0.96 & 2.22 & 41.40 & 9.59 & 0.01 \\
\hline \multicolumn{8}{|l|}{ Religion } \\
\hline Christian & 1 & 34 & 0.32 & & & & 1 \\
\hline Muslim & 4 & 175 & 1.27 & 0.14 & 1.78 & 0.49 & 0.34 \\
\hline Druze & 3 & 62 & 0.96 & 0.42 & 6.66 & 1.67 & 0.44 \\
\hline Bedouin & 2 & 31 & 0.64 & 0.45 & 10.83 & 2.2 & 0.28 \\
\hline
\end{tabular}

* Fisher's test; ${ }^{\dagger} 2$ patients did not answer the question, one from each group (KC and Normal)

Table 4: Epidemiological studies of $\mathrm{KC}$ in the middle-east

\begin{tabular}{|c|c|c|c|c|c|c|}
\hline Author & Location & Age (years) & Sample size & Incidence & Prevalence & Source \\
\hline Assiri et al, ${ }^{12} 2005$ & Asir, Saudi Arabia & $8-28$ & $125-\mathrm{P}$ & $20 / 100,000$ & & Hospital \\
\hline Millodot et al, ${ }^{8} 2011$ & Jerusalem, Israel & $18-54$ & 981 & & $2340 / 100,000$ & $\begin{array}{l}\text { College student } \\
\text { population }\end{array}$ \\
\hline Waked et al, ${ }^{9} 2012$ & Lebanon & $22-26$ & 92 & & $3300 / 100,000$ & $\begin{array}{l}\text { Medical student } \\
\text { population }\end{array}$ \\
\hline Ziaei et al, ${ }^{32} 2012$ & Yazd province, Iran & & 536 & $22.3 / 100,000$ & & Population \\
\hline Hashemi et al, ${ }^{11} 2013$ & Shahrud, Iran & $40-64$ & 4592 & & $830 / 100,000$ & Population \\
\hline Hashemi et al, ${ }^{10} 2013$ & Tehran, Iran & $14-81$ & 442 & & $3300 / 100,000$ & Population \\
\hline Current study & Haifa, Israel & $18-60$ & 314 & & $3180 / 100,000$ & $\begin{array}{l}\text { College student } \\
\text { population }\end{array}$ \\
\hline
\end{tabular}

This study identified an association between $\mathrm{KC}$ and years of education, similar to a previous study in the region. ${ }^{24}$ The reason is still not clear, but may be an ascertainment bias as more educated people are more likely to participate in such a research study.

There are several limitations to this study. The sample size may be too small to provide a precise estimate of the prevalence of KC. In addition, the small sample size resulted in only ten subjects with $\mathrm{KC}$, which lowers the power when identifying risk factors. The data tended to indicate the higher prevalence in Druzes and Bedouins, but this result needs to be viewed with caution because of the very small sample. It must be noted though, that these ethnics groups live in small villages were consanguinity and endogamy are common, ${ }^{66}$ a known risk factor for KC. ${ }^{24}$ Further research is needed to corroborate the results of this study. The sample population is a non-random group of individuals obtained from college students in Haifa who voluntarily presented themselves for a corneal topographic examination and questionnaire. A selection bias may have occurred since individuals who knew they had the disease may have refrained from participating in the study because they were under ophthalmic care, while others with visual problems may have been more likely to volunteer. As in most studies, the assessment of risk factors depended on the information given in the self-administered questionnaire, which may be biased by the fact that the ability of subjects to report earlier experiences differs.

\section{CONCLUSION}

We recommend that children who have consanguinity in the family should do topography of the cornea at a young age in order to detect early stages of $\mathrm{KC}$, especially as in this study $60 \%$ of the detected cases were unaware that they had the disease.

\section{ACKNOWLEDGMENT}

The authors are thankful to Ana Bathish, Ahmed Dabbah, Warde Zreeqe, Sewar Jamal and Hanan Younis for help 
in data collection and processing. In addition, we want to thank the students and staff of the Arab Academic College of Education and Technology who participated in this study and especially to the head of the college, Professor Salman Elayan and to Dr Nabih Elqassem for their help in facilitating this study.

\section{REFERENCES}

1. Krachmer JH, Feder RS, Belin MW. Keratoconus and related noninflammatory corneal thinning disorders. Surv-Ophthalmol 1984;28(4):293-322.

2. Rabinowitz YS. Keratoconus. Surv-Ophthalmol 1998;42(4):297319.

3. Tuft SJ, Moodaley LC, Gregory WM, Davison CR, Buckley RJ. Prognostic factors for the progression of keratoconus. Ophthalmology 1994;101(3):439-447.

4. Ertan A, Muftuoglu O. Keratoconus clinical findings according to different age and gender groups. Cornea 2008;27(10): 1109-1113.

5. Yildiz EH, Erdurmus M, Hammersmith KM, Rapuano CJ, Laibson PR, Cohen EJ. Comparative study of graft rejection in keratoconus patients with and without self-reported atopy. Cornea 2009;28(8):846-850.

6. Choi JA, Kim MS. Progression of keratoconus by longitudinal assessment with corneal topography. Invest Ophthalmol Vis Sci. 2012;53(2):927-935.

7. Jonas JB, Nangia V, Matin A, Kulkarni M, Bhojwani K. Prevalence and associations of keratoconus in rural Maharashtra in central India: the central India eye and medical study. Am J Ophthalmol 2009;148(5):760-765.

8. Millodot M, Shneor E, Albou S, Atlani E, Gordon-Shaag A. Prevalence and associated factors of keratoconus in Jerusalem: a cross-sectional study. Ophthalmic Epidemiology 2011;18(2): 91-97.

9. Waked N, Fayad A, Fadlallah A, El Rami H. Keratoconus screening in a Lebanese students' population. J Fr Ophtalmol 2012; 35:(1):23-29.

10. Hashemi H, Khabazkhoob M, Fotouhi A. Topographic Keratoconus is not Rare in an Iranian population: the Tehran Eye Study. Ophthalmic Epidemiol 2013;20(6):385-391.

11. Hashemi H, Beiranvand A, Khabazkhoob M, Asgari S, Emamian MH, Shariati M, et al. Prevalence of Keratoconus in a Population-based Study in Shahroud. Cornea 2013;32(11):14411445.

12. Assiri AA, Yousuf BI, Quantock AJ, Murphy PJ. Incidence and severity of keratoconus in Asir province, Saudi Arabia. Br J Ophthalmol 2005;89(11):1403-1406.

13. Hodge $\mathrm{C}$, Chan $\mathrm{C}$, Sutton G. Investigation of keratoconus in an Australian refractive population. Clinical and experimental ophthalmology 2014.

14. Hofstetter HW. A keratoscopic survey of 13,395 eyes. American journal of optometry and archives of American Academy of Optometry 1959;36(1):3-11.

15. Kennedy RH, Bourne WM, Dyer JA. A 48-year clinical and epidemiologic study of keratoconus. Am J Ophthalmol 1986;101(3):267-273.

16. Ihalainen A. Clinical and epidemiological features of keratoconus genetic and external factors in the pathogenesis of the disease. Acta ophthalmologica Supplement 1986;178:1-64.
17. Gorskova EN, Sevost'ianov EN. Epidemiology of keratoconus in the Urals. Vestn-Oftalmol 1998;114(4):38-40.

18. Pearson AR, Soneji B, Sarvananthan N, Sandford-Smith JH. Does ethnic origin influence the incidence or severity of keratoconus? Eye (Lond) 2000;14(Pt 4):625-628.

19. Georgiou T, Funnell CL, Cassels-Brown A, O'Conor R. Influence of ethnic origin on the incidence of keratoconus and associated atopic disease in Asians and white patients. Eye (Lond). 2004;18(4):379-383.

20. Nielsen K, Hjortdal J, Aagaard Nohr E, Ehlers N. Incidence and prevalence of keratoconus in Denmark. Acta ophthalmologica Scandinavica 2007;85(8):890-892.

21. Kenney MC, Brown DJ. The cascade hypothesis of keratoconus. Cont lens Anterior Eye 2003;139-146.

22. Tanabe U, Fujiki K, Ogawa A, Ueda S, Kanai A. Prevalence of keratoconus patients in Japan. Nihon Ganka Gakkai Zasshi. 1985;89(3):407-411.

23. Pan CW, Cheng CY, Sabanayagam C, Chew M, Lam J, Ang M, et al. Ethnic variation in central corneal refractive power and steep cornea in asians. Ophthalmic epidemiology 2014;21(2): 99-105.

24. Gordon-Shaag A, Millodot M, Essa M, Garth J, Ghara M, Shneor E. Is consanguinity a risk factor for keratoconus? Optom Vis Sci. 2013;90(5):448-454.

25. Xu L, Wang YX, Guo Y, You QS, Jonas JB, Group BES. Prevalence and associations of steep cornea/keratoconus in Greater Beijing. The Beijing Eye Study. PloS one 2012;7(7):e39313.

26. Owens H, Gamble G. A profile of keratoconus in New Zealand. Cornea 2003;22(2):122-125.

27. Gordon-Shaag A, Barnard S, Millodot M, Gantz L, Chiche G, Elbaz V, et al. Prevalence of choroidal nevi using Scanning Laser Ophthalmoscope. Ophth and Phys Optics 2014;34(1): 94-101.

28. Shneor E, Millodot M, Blumberg S, Ortenberg I, Behrman S, Gordon-Shaag A. Characteristics of 244 patients with keratoconus seen in an optometric contact lens practice. Clinical and experimental optometry: journal of the Australian Optometrical Association 2013;96(2):219-224.

29. Markus B, Alshafee I, Birk OS. Deciphering the fine-structure of tribal admixture in the Bedouin population using genomic data. Heredity (Edinb) 2014;112(2):182-189.

30. Rabinowitz YS, Rasheed K. KISA\% index: a quantitative videokeratography algorithm embodying minimal topographic criteria for diagnosing keratoconus. J Cataract Refract-Surg 1999;25(10):1327-1335.

31. Gordon-Shaag A, Millodot M, Shneor E. The epidemiology and etiology of keratoconus. International Journal of Keratoconus and Ectatic Corneal Disease 2012;1(1):7-15.

32. Ziaei H, Jafarinasab MR, Javadi MA, Karimian F, Poorsalman $\mathrm{H}$, Mahdavi M, et al. Epidemiology of keratoconus in an Iranian population. Cornea 2012;31(9):1044-1047.

33. Cohen T, Vardi-Saliternik R, Friedlander Y. Consanguinity, intracommunity and intercommunity marriages in a population sample of Israeli Jews. Ann Hum Biol 2004;31(1):38-48.

34. Vardi-Saliternik R, Friedlander Y, Cohen T. Consanguinity in a population sample of Israeli Muslim Arabs, Christian Arabs and Druze. 2002;4(29):422-431.

35. Bittles AH. Endogamy, consanguinity and community disease profiles. Community Genet 2005;8(1):17-20.

36. El-Kheshen G, Saadat M. Prevalence of consanguineous marriages among shi'a populations of Lebanon. J Biosoc Sci 2013;45(5):672-682. 
37. Saadat M, Ansari-Lari M, Farhud DD. Consanguineous marriage in Iran. Ann Hum Biol 2004;31(2):263-269.

38. Fathzadeh M, Babaie Bigi MA, Bazrgar M, Yavarian M, Tabatabaee HR, Akrami SM. Genetic counseling in southern Iran: consanguinity and reason for referral. J Genet Couns 2008;17(5):472-479.

39. El-Mouzan MI, Al-Salloum AA, Al-Herbish AS, Qurachi MM, Al-Omar AA. Regional variations in the prevalence of consanguinity in Saudi Arabia. Saudi Med J 2007;28(12):1881-1814.

40. Al-Abdulkareem AA, Ballal SG. Consanguineous marriage in an urban area of Saudi Arabia: rates and adverse health effects on the offspring. Journal of community health 1998;23(1):75-83.

41. Rabinowitz YS. The genetics of keratoconus. Ophthalmology clinics of North America 2003;16(4):607-620.

42. Owens H, Gamble G. A profile of keratoconus in New Zealand. Cornea 2003;22(2):122-125.

43. Szczotka-Flynn L, Slaughter M, McMahon T, Barr J, Edrington T, Fink B, et al. Disease severity and family history in keratoconus. BrJ Ophthalmol 2008;92(8):1108-1111.

44. Hughes AE, Dash DP, Jackson AJ, Frazer DG, Silvestri G. Familial keratoconus with cataract: linkage to the long arm of chromosome 15 and exclusion of candidate genes. Invest Ophthalmol Vis Sci 2003;44(12):5063-5066.

45. Karimian F, Aramesh S, Rabei HM, Javadi MA, Rafati N. Topographic evaluation of relatives of patients with keratoconus. Cornea 2008;27(8):874-878.

46. Millodot M, Shneor E, Albou S, Atlani E, Gordon-Shaag A. Prevalence and associated factors of keratoconus in Jerusalem: a cross-sectional study. Ophthalmic Epidemiol 2011;18(2):91-97.

47. Weed KH, MacEwen CJ, McGhee CN. The variable expression of keratoconus within monozygotic twins: dundee University Scottish Keratoconus Study (DUSKS). Cont Lens Anterior Eye 2006;29(3):123-126.

48. Bechara SJ, Waring GO III, Insler MS. Keratoconus in two pairs of identical twins. Cornea 1996;15(1):90-93.

49. Tuft SJ. Keratoconus in 18 pairs of twins. Acta Ophthalmol 2012;90(6):482-486.

50. Edwards M, McGhee CN, Dean S. The genetics of keratoconus. Clin Experiment Ophthalmol 2001;29(6):345-351.

51. Sugar J, Macsai MS. What causes keratoconus? Cornea 2012;31(6):716-719.

52. Bisceglia L, Ciaschetti M, De Bonis P, Campo PA, Pizzicoli C, Scala C, et al. VSX1 mutational analysis in a series of Italian patients affected by keratoconus: detection of a novel mutation. Invest Ophthalmol Vis Sci 2005;46(1):39-45.

53. Burdon KP, Macgregor S, Bykhovskaya Y, Javadiyan S, Li X, Laurie KJ, et al. Association of polymorphisms in the hepatocyte growth factor gene promoter with keratoconus. Invest Ophthalmol Vis Sci 2011;52(11):8514-8519.

54. Bykhovskaya Y, Li X, Epifantseva I, Haritunians T, Siscovick $\mathrm{D}$, Aldave A, et al. Variation in the lysyl oxidase (LOX) gene is associated with keratoconus in family-based and case-control studies. Invest Ophthalmol Vis Sci 2012;53(7):4152-4157.

55. Gajecka M, Radhakrishna U, Winters D, Nath SK, Rydzanicz $\mathrm{M}$, Ratnamala $U$, et al. Localization of a gene for keratoconus to a $5.6-\mathrm{Mb}$ interval on $13 \mathrm{q} 32$. Invest Ophthalmol Vis Sci 2009;50(4):1531-1539.

56. Li X, Rabinowitz YS, Tang YG, Picornell Y, Taylor KD, Hu $\mathrm{M}$, et al. Two-stage genome-wide linkage scan in keratoconus sib pair families. Invest Ophthalmol Vis Sci 2006;47(9):37913795.

57. Li X. Genetic association of COL5A1 variants in keratoconus patients suggests a complex connection between corneal thinning and keratoconus. Invest Ophthalmol Vis Sci 2013;54(4):26962704.

58. Lu Y, Vitart V, Burdon KP, Khor CC, Bykhovskaya Y, Mirshahi $\mathrm{A}$, et al. Genome-wide association analyses identify multiple loci associated with central corneal thickness and keratoconus. Nature genetics 2013;45(2):155-163.

59. Gao X, Gauderman WJ, Liu Y, Marjoram P, Torres M, Haritunians T, et al. A genome-wide association study of central corneal thickness in Latinos. Invest Ophthalmol Vis Sci 2013; 54(4):2435-2443.

60. Bae HA, Mills RA, Lindsay RG, Phillips T, Coster DJ, Mitchell $\mathrm{P}$, et al. Replication and meta-analysis of candidate loci identified variation at RAB3GAP1 associated with keratoconus. Invest Ophthalmol Vis Sci 2013;54(7):5132-5135.

61. Li X, Bykhovskaya Y, Haritunians T, Siscovick D, Aldave A, Szczotka-Flynn L, et al. A genome-wide association study identifies a potential novel gene locus for keratoconus, one of the commonest causes for corneal transplantation in developed countries. Hum-Mol-Genet 2012;21(2):421-429.

62. Liskova P, Hysi PG, Waseem N, Ebenezer ND, Bhattacharya SS, Tuft SJ. Evidence for keratoconus susceptibility locus on chromosome 14: a genome-wide linkage screen using singlenucleotide polymorphism markers. Arch Ophthalmol 2010; 128(9):1191-1195.

63. Tang YG, Rabinowitz YS, Taylor KD, Li X, Hu M, Picornell Y, et al. Genomewide linkage scan in a multigeneration Caucasian pedigree identifies a novel locus for keratoconus on chromosome. Genet Med 2005;7(6):397-405.

64. Tyynismaa H, Sistonen P, Tuupanen S, Tervo T, Dammert A, Latvala $\mathrm{T}$, et al. A locus for autosomal dominant keratoconus: linkage to 16q22.3-q23.1 in Finnish families. Invest Ophthalmol Vis Sci 2002;43(10):3160-3164.

65. Wheeler J, Hauser MA, Afshari NA, Allingham RR, Liu Y. The genetics of keratoconus: a review. Reproductive system and sexual disorders: current research 2012;(Suppl 6).

66. Raz AE, Atar M. Cousin marriage and premarital carrier matching in a Bedouin community in Israel: attitudes, service development and educational intervention. J Fam Plann Reprod Health Care 2004;30(1):49-51. 